\title{
Essence of Time in Construction Contracts
}

Tony Lim (Doyles Construction Lawyers, Australia)

\author{
ABSTRACT
}

The building industry has in recent years seen huge costs incurred due to disputes arising on notice requirement clauses. These claims could have been averted if the parties had been diligent in providing the necessary notices. This article sets out to explore the law briefly as interpreted by the courts in common law and equity and discuss the possibility of defence under the principle of promissory estoppel. More importantly it also shares the author's view on how such pitfalls could have been prevented by giving the proper notices within the timeline required by the contract conditions. It cannot be emphasised enough that contractors would be wise to comply strictly with the notice provisions in the contract instead of relying on the estoppel principle or waiver or unconscionability to save their day. Notice clauses essentially require a competent contracts administrator to follow the time line provided in the contract conditions and would be most effective if the project team worked closely with the contracts administrator to ensure that proper notices are given when directions or instructions are received. Although it is common to see notice clauses which make it a condition precedent for a contractor to be entitled to claim for an extension of time or loss and expense claim being interpreted restrictively, in any litigation or arbitration it is always difficult to predict how the courts or tribunal would be willing to uphold such notice clause. It is therefore in the interest of the parties that notice clauses should be properly observed. Suffice to say, failure to comply with a notice clause and time bar may be fatal to a claim.

Keywords: extensions of time, liquidated damages, condition precedent, estoppel, unconscionability, building contracts.

\section{INTRODUCTION}

The effect of time stipulations and time limitation clauses in construction contracts have traditionally been interpreted by the courts of common law and equity differently.

At common law, time stipulations have been usually treated as essential terms and a failure to meet a due date will give the innocent party the right to terminate the agreement and to recover damages. As a result, time was considered to be "of the essence" of the contract, unless expressly agreed to the contrary.

The courts of equity however adopted a more liberal view of time stipulations making a distinction between "form and substance" and adopting the general rule that "performance on time was not essential if the substance of the contract could be carried out and the promisee adequately compensated for loss or damage caused by the promisor's breach" [1]. However, time could be made of the essence where it had been unequivocally agreed [2] or could reasonably be implied in the circumstances.

Today, equity prevails and time will only be of the essence where it has been expressly agreed or where it may be implied.
Where time is not expressly made of the essence, it will be a matter of construction to determine whether the contract indicates an implied agreement that time is to be a condition [3]. When making such an assessment, courts will usually consider factors such as:

1. the form of words used;

2. the circumstances surrounding the contract;

3. the nature of the subject matter [4];

4. whether the contract is commercial in character;

5. the relationship between various terms in the contract; and

6. the nature of the obligation to which the time stipulation applies.

In relation to the form of words used, courts tend to adopt a hierarchical approach. Phrases such as "proceed with all due dispatch" [5], "on or about", "within a reasonable time" or "as soon as possible" [6] imply that the parties did not intend to make time of the essence. By comparison, expressions such as "at the latest by" [7] or "within a number of days" would imply that the parties did intend to make time to be of the essence.

\section{COMMON PHRASES IN TIME LIMITATION CLAUSES}

\section{A REASONABLE TIME}

A "reasonable time" was considered by the House of Lords in the case of Stickney $v$ Keeble [8], which involves the question of whether a period of notice was reasonable. In this case, although time fixed for completion on the sale of land was not made the essence of the contract, it was held that the purchaser could nevertheless serve upon the vendor a notice limiting a time at the expiration of which he will treat the contract at an end.

A reasonable time means a reasonable time under ordinary circumstances, and in the absence of some stipulation altering the implied contract between the parties the vendors would not be relieved from the consequences of fortuitous or unforeseen impediments affecting only the due performance by them of their part of the contract [9].

\section{AS SOON AS POSSIBLE}

When used in contract these words, "as soon as possible" mean that an act promised will be done within a reasonable time and undertake that it will be done in the shortest practicable time [10]. In determining what is commercially possible, the courts will usually consider the surrounding circumstances, even though the limited resources of the contracting may not be relevant. Consequently, it would be advisable that a party to a contract 
should hesitate before undertaking to do something "as soon as possible".

\section{RELATIONSHIP BETWEEN VARIOUS TERMS AND LIQUIDATED DAMAGES}

The relationship between various terms in a contract is demonstrated by the case of Lamprell $v$ Guardians of the Poor of the Billericay Union [11] where it was held that stipulations as to time should rarely be implied as essential in contracts which provide for payment of liquidated damages for failing to complete by the due date. In that case, the fact that the contract otherwise provided a mechanism for compensating the principal by way of liquidated damages was indicative that the parties did not intend time to be of the essence.

The payment of liquidated damages is also seen as a mechanism that prevents time becoming at large to the contracting parties. In the English case of Peak Construction (Liverpool) Ltd v McKinney Foundations Ltd [12] it was held that where an employer delayed the contractor and there was no provision in the contract for an extension of time to cover the employer's delay, the employer could no longer insist on completion by the original completion date. The contractor would accordingly be only required to complete within a reasonable time.

\section{TIME LIMITATION CLAUSES IN CONSTRUCTION CONTRACTS}

Since construction projects inevitably involve a number of activities that are dependent and interconnected on internal and external factors to the project, construction contracts generally do not state expressly that time is of the essence.

In addition, even if one clause states that time is of the essence, this does not necessarily mean that it is a condition of the contract that time for performance of all other terms is also of the essence [13].

Consequently, it will be a matter of construction as to whether time is of the essence in a building contract. Typically, unless the parties explicitly state that time is of the essence or it is reasonable to imply that that was the parties' intention, performance on time will be a warranty rather than a condition. However, even where time is a condition, it may be a condition only in relation to certain obligations under the agreement - such as the provision of notices.

Since the English case of Hong Kong Fir Shipping Ltd v Kawasaki Kisen Kaisha Limited [14] where Diplock LJ (at pp.69-70) emphasised that a contract may stand somewhere between a condition and a warranty was classified as an intermediate or innominate term which is capable of operating according to the gravity of the breach as either a condition or warranty. The courts in Australia and Singapore since Hong Kong Fir have recognised this term in their judgments [15].

\section{INTERPRETATION OF TIME LIMITATION CLAUSES}

Time limitation clauses originate from exclusion clauses and accordingly, they operate for the benefit of one party [16] and they qualify a party's rights or remedies by subjecting them to a specified procedure.

In Sydney Corp $v$ West [17] it was held that the meaning of an exclusion clause is to be determined by the intention of the parties as evidenced by the terms of the contract and, as a consequence, a number of rules of construction have developed over time [18].
One such rule is the contra proferentum rule which states that an exclusion clause may be construed strictly against the party for whose benefit it is intended to operate.

The case of Tropicon Contractors Pte Ltd v Lojan Properties $P t e ~ L t d$ [19] demonstrates the interpretation given to a time limitation clause. The case focuses on the project architect issuing a whole new set of seventeen interim certificates disallowing previously granted extensions of time on the ground of failure by the contractor to give the initial notices in time, and theoretically deducting sums by way of liquidated damages in those new certificates, while also issuing a delay certificate and a new general monetary certificate showing a net sum due to the employer after allowing for the resulting liquidated damages. The contractors had issued a writ and applied for summary judgment claiming the outstanding sums under twelve unpaid interim certificates [20].

It was held by LP Thean $\mathrm{J}$ [as he then was], and this was upheld by the Court of Appeal, that the delay certificate was not valid because it was not issued at the time stipulated in clause 24.1, i.e. "as soon as the latest date" for completion had passed. The learned judge also found that the purported revised extension of time was defective because it was not made within the time provided by clause 23.3; the delaying factor had occurred more than three years before and presumably had ceased to operate long before the purported extension.

\section{CONDITION PRECEDENT}

A time limitation clause in a building construction contract may be construed to be a condition precedent when a time limit is imposed on an act to be performed by one of the parties.

The distinction between a "condition precedent to a contract" and a "condition precedent to an obligation" [21] is that in the former case, the specified event occurs prior to the formation of a contract. Therefore, if the event fails to occur, the non-performing party cannot be said to have breached the contract. In the latter case, the specified event occurs while a contract is still on foot. In this situation, a failure to perform may give rise to damages or act as a bar to other contractual provisions.

There have been a number of cases which have looked at whether time procedures in building construction contracts constitute a condition precedent to a claim. In this context, the condition precedent does not relate to the existence of the contract itself but rather to an obligation. This has the result that the specified event may be waived by the party for whom the obligation was designed to benefit.

One such case is Assoland Construction Pte Ltd v Malayan Credit Properties Pte Ltd [22]. Assoland entered into a main contract with Malayan Credit for the construction of "the Abelia", a 12-storey apartment building with a basement car park using the 1987 revised version of the standard form of contract of the Singapore Institute of Architects ("SIA Conditions"). The contract was scheduled for completion on 19 September 1991 but remained incomplete as of that date. Assoland made applications to the architect pursuant to clause 23.2 of the SIA Conditions. Clause 23.2 reads:

It shall be a condition precedent to an extension of time by the architect under any provision of this Contract including the present clause (unless the architect has already informed the Contractor of his willingness to grant extension of time) that the Contractor shall within 28 days notify the architect in writing of any event or direction or instruction 
which he consider entitles him to an extension of time, together with a short statement of the reasons why delay to completion will result. Upon receipt of such notification the architect shall inform the Contractor in writing within 1 month of its receipt whether or not he considers the event or instruction or direction in principle entitles the Contractor to an extension of time. (Emphasis added)

The architect did not respond to the notices given by Assoland as they were required to under clause 23.2 .

On 20 July 1992 the architect wrote to the developers stating, inter alia, that:

1. the date of completion was extended to 31 January 1992 and the delay certificate will be issued thereafter; and

2. the date of practical completion will be 1 July 1992.

On 31 July 1992 the architect issued a certificate of completion certifying that the works were practically completed on 1 July 1992.

On 4 November 1992, the architect issued a delay certificate extending the completion of the works only to 24 April 1992.

Malayan Credit relied on the delay certificate to set off liquidated damages of about $\$ 204,000.00$ from Assoland's claim for payment made under the architect's interim certificates of payment.

Assoland disputed the set-off. They argued that the delay certificate was invalid because the architect in granting the extension of time did not comply with the requirements in clause 23.2 .

The court agreed with Assoland that the one month in principle notice to be given by the architect was a condition precedent to any exercise of the architect's powers of extension of time.

The honourable Judicial Commissioner Goh Phai Cheng held, inter alia, that the architect's failure to comply with the procedural requirements in Clause 23.2 meant that the purported exercise of power to later grant an extension of time was invalid. As such there was no date by which liquidated damages could be computed.

On another time related case Aoki Corp v Lippoland (Singapore) Pte Ltd [23] the High Court in Singapore took a different approach. The parties entered into a building contract using the standard SIA conditions of contract. Aoki had sued on two interim payment certificates for sums totalling $\$ 992,413.80$. Lippoland pleaded by way of set-off and counterclaim for a sum of $\$ 1,080,581.29$ as liquidated damages by reason of delay in the completion of the works. The senior assistant registrar gave judgment in favour of Aoki in the sum claimed by them, but ordered a stay on Lippoland counterclaim for liquidated damages pending arbitration. Lippoland then appealed against both decisions of the senior assistant registrar and the matter was heard by Warren Khoo J (as he then was).

Counsel for Aoki amongst other cases, cited Assoland Construction Pte Ltd v Malayan Credit Properties Pte Ltd [24] mentioned above, where the learned judicial commissioner noted the two stages involved in the processing of claims for extensions of time, i.e. the preliminary in-principle intimation under clause 23.2 and the final decision on the quantum of extension under clause 23.3.
In Aoki however, his Honour's decision was simply to find whether the failure by the architect to give his intimation in principle within the one-month period renders his subsequent determination on the extension of time invalid for the purpose of the summary judgement proceedings.

His Honour found that on a plain reading of clause 23.2, the contract did not make the in-principle intimation within the one-month period a condition precedent for the validity of the determination. It was, in his Honour's view, of some significance that while notification by the contractor of a delay event within 28 days of its occurrence is expressly made a condition precedent to an extension of time, the architect's in-principle intimation within the one-month period was not expressed to be a condition precedent to the validity of his subsequent decision on the quantum.

The reason for making the timely notification by the contractor of a delay event a condition precedent to an extension of time was to enable the employer or the architect to verify the claim for extension and to monitor the event and its impact on the progress of the works. In the case of the in-principle intimation by the architect, his Honour was of the view that there was no compelling need for the draftsman to make it a condition precedent, and doing so would impose difficulty for the architect to commit himself to a view that 'in principle' the contractor was entitled to an extension without evaluating the effect of the delay event.

While it was the contention of Aoki that the purported extension of 15 days was invalid because there had been no preliminary in-principle intimation that the architect would grant such an extension, it was not suggested by them that the decision on the quantum of the extension was not made within the time provided in clause 23.3 , i.e. as soon as the delay factor had ceased and it was possible to determine the length of extension. For the reasons set out above, his Honour did not think that the omission by the architect to give the in-principle intimation had the effect suggested by Aoki.

His Honour then went on to discuss inter alia, the progress payments and agreed that these were the lifeline of a building contractor's business. It was held that Aoki were entitled to summary judgment for the amounts certified in the interim certificates. Lippoland, on the other hand, were also entitled to deduct the amount of the liquidated damages consequent on the delay in the completion of the works. His Honour found no reason why Lippoland's claim for the liquidated damages should be stayed.

When assessing whether a time stipulation in a construction contract is a condition precedent to a claim, it is necessary to assess the intention of the parties when negotiating the contract and deciding upon the procedure for making a claim. Where the parties have expressed a procedure and set time limits for submitting a claim, this will be highly persuasive that the parties intended that procedure to be a condition precedent.

\section{WHETHER TIME IS OF THE ESSENCE BEING A CONDITION PRECEDENT}

The two principles on whether the doctrines when time for giving notices was of the essence and a condition precedent to a claim for an extension of time especially where the employer has clearly delayed the contractor in completing the works was considered in Leighton Contractors Pty Ltd v SA Superannuation Fund Investment Trust [25]. This case concerned the construction of a major commercial building where an extensively modified version 
of the standard Joint Construction Agreement with a contract sum of approximately $\$ 34$ million, was entered by the parties, a commencement date of 15 May 1987, and a date for practical completion of 6 February 1989 (which was subsequently extended by the architect to 22 February 1989) was inserted into the contract.

The building consisted, in part, of pre-cambered concrete floors and a dispute arose between the parties as to whether the floors were installed and leveled in accordance with the specifications. Leighton contended that the floors were in compliance with the tolerance requirements when they were installed and that it was inappropriate to test the floors once they had settled under their own weight. SA claimed that the finish of the floors was unacceptable and the architect issued instructions to the builder to rectify the work.

Leighton undertook the rectification work and later attempted to claim the works as a variation. The matter was referred to arbitration as required under the contract. The builder claimed for bonuses, variations, finance charges, interest and administrative costs in the sum of approximately $\$ 25,000,000$. SA claimed for defective works and was awarded a sum of approximately $\$ 440,000$ plus interest. Leighton appealed to the Supreme Court of South Australia on grounds (inter alia) that the arbitrator had erred in his construction of the notice provisions of the contract in relation to variations.

The contract provides for the architect under clause 6.10 with the right to issue variations to the contractor and makes provisions for the contractor to claim an adjustment to the contract sum and the date for practical completion; however, all variations were required to be authorised in writing by the architect and certified by the proprietor before the variation work could commence.

The contractor was required under clause 9.01 to give written notice to the architect within 10 working days after the delay occurs. Clause 15.09 .04 then provides that:

1. Time shall be of the essence as regards the service by the builder of all notices required to be given by the builder pursuant to s 9 of the general conditions and this subs 15.09;

2. The service by the builder upon the proprietor and/or the architect of any notice or notices required to be given by the builder shall be conditions precedent to the substantiation and pursuit by the builder of any claim for an extension of time.

Thus, the contract purported that time for giving notices was of the essence and a condition precedent to a claim for an extension of time.

Leighton asserted that the architect's instructions amount to a variation and that it was unable to assess the delay until the entire project had been completed. As a consequence, under clause 9.01, it was not in a position to claim an extension of time until the end of the project.

SA however, claimed that the architect's prior approval to the works was a condition precedent to any claim for a variation, and as such, the contractor was prohibited from making a claim. King CJ held:

Mr Gray contended that the arbitrator erroneously interpreted clause 6.09.02 as making the time for notice of the essence of the contract. This seems to me to be something of an irrelevance... The stipulation in clauses
6.09.02 and 15.11 .01 is that notice be given prior to carrying out the work. That is not a time stipulation. The giving of notice prior to commencing work is a condition precedent to claiming for the work as a variation. No question of time arises. The stipulation is mandatory and the right to claim for variation is contingent upon compliance. (Emphasis added)

His Honour usefully illustrated the practical difference between these two doctrines in relation to claims for variations or extensions of time. Where time is of the essence, a failure to meet that condition can constitute a fundamental breach of the agreement and allows the aggrieved party to terminate the contract. By comparison, where time is a condition precedent, if that mandatory requirement is not met the subsequent obligations cannot arise. In other words, in the former scenario time was destructive of the contract; whereas in the latter, time was constructive of the obligation.

\section{DEFENCES TO TIME BARS}

Time limitation clauses have always been a common feature in construction contracts. In determining whether they are to be treated as exclusion clauses it would be necessary to consider the intention of the parties such as whether an enforcement of the clause would lead to an absurdity or defeat the main object of the contract [26]. Where a party has failed to comply with the conditions as required, it may still be possible to defeat the time limitation clause if a defence can be made out in waiver or estoppel. In order to establish waiver, it will be necessary to show that the party seeking to rely on the exclusion clause has either unambiguously discarded that right or chosen to exercise an alternative inconsistent right.

For example, waiver on the part of the employer can arise where the employer waives his right to strict compliance with the terms of the contract, such as the time stipulation clauses [27]. When this occurs, it can be used as indicating a non-insistence upon a right either expressly stated or by conduct, where late claims in the past have been dealt with. That is, if the right to require strict compliance with a time stipulation clause is abandoned, then the other party is entitled to use that fact in its defence.

Once the right has been waived, the contractor can claim that it had acted in reliance on the release or abandonment to its detriment, i.e. by not submitting its claim within the time specified and therefore possibly putting itself in a position where its claim is extinguished. In the case of Lian Soon Construction Pte Ltd $v$ Guan Qian Realty Pte Ltd [28] it was held by Warren Khoo J that although the contractor may have breach the notice provisions under clause 23.2 of the SIA Conditions but because the architect having departed from the procedures set out in the contract conditions the conditions precedent requirements were waived.

To be successful in an application to time limitation, the contractor would need to prove that he had relied on the representation of the employer that it would not require the strict notice provision as a bar to subsequent claim by the contractor. In such circumstances, since the representation relates to future conduct, the contractor would need to show:

1. that there was an actual representation made by the employer;

2. the contractor relied upon that representation;

3. the contractor has or will suffer detriment if the employer were not held to the representation; and 
4. that it would be unconscionable in the circumstances for the principal to act contrary to the representation.

Where the representation relates to existing facts, the estoppel may be grounded in common law or equity but where the representation relates to future conduct, the estoppel will be promissory estoppel and it will be necessary to establish that it would be unconscionable to rely on the time limitation. Typically, representations made by an employer that it will not rely on a time limitation will be promises as to future conduct, and a claim of estoppel may be made in equity. The courts usually look primarily at the conduct of the party to determine whether that party's conduct could form the basis of a claim that the time limitation should not apply. In establishing estoppel, the party seeking to rely on the time limitation must show that they had relied on the representation made by the other party to its detriment.

Detriment may be caused where the contractor had relied on an assumption brought about by the words or conduct of the employer which, if denied, would result in injustice. For example, if the employer says "don't worry, just get the job done as soon as possible", then the contractor may not have to comply within the time line required. If that assumption is denied by the employer, then the detriment to the contractor is obvious and demonstrable. Unfortunately, even an assertion of waiver may be required by the terms of the contract to be in writing.

The issue of unconscionability was considered in the case of Waltons Stores (Interstate) Ltd v Maher [29] where the doctrine of promissory estoppel was extended to the enforcement of voluntary promises that a departure from the basic assumption underlying the transaction between the parties must be unconscionable. In this case, Maher (the "landlord") entered into negotiations with Waltons Stores (Interstate) Ltd (a potential "tenant") to discuss the tenant's specification which among other things included the demolition of an existing building and erecting a new one to meet the needs of the tenant. It was established during the trial that major negotiations took place in the first two weeks of November 1983 to finalise the lease and the negotiations went into overdrive due to approaching year-end holidays and the tight schedule imposed on the landlord to complete the new building. After further discussions which included a request of extension of time by the landlord, it was agreed that the new building will be available for fitting out by 15 January and completed by 5 February 1984 . The lease was then executed by the landlord and returned to the tenant's lawyers. The landlord then proceeded with the demolition works until 19 January 1984 when they were notified by their lawyers that the tenant's lawyers had written to inform that the tenant did not intend to proceed with the lease. By then extensive works had already been carried out on site with the knowledge of the tenant.

The court found that the appellant (tenant) was under an obligation to communicate with the respondents within a reasonable time after receiving the executed counterpart deed and certainly when it learnt that the respondent (landlord) was proceeding with the demolition of the existing building. It was held that the appellant was estopped from denying the existence of a binding contract. They have to choose whether to complete the contract or to warn the respondents that it had not yet decided upon the course it would take.

Unconscionability was also considered in the case of Abigroup Contractors Pty Ltd v Sydney Catchment Authority [30] where the contractor had alleged that a report produced by the employer was found to be ambiguous. The employer claimed that the contractor's acceptance of the report was itself a representation from which the contractor was estopped from resiling. However, the court found that since the contractor was induced to give the representation by the unconscionable conduct of the employer, the contractor's representation that it accepted the report was not itself unconscionable.

Generally, the equitable approach had prevailed and time will only be of the essence where it is expressly stated to be so or where it may reasonably be implied. Factors such as the presence of liquidated damages tend to imply that parties did not anticipate time stipulations to be conditions.

An intermediate term lies somewhere between a condition and a warranty and have also been described as "innominate" terms. Whether a term is intermediate in character will depend largely on the construction of the contract and the intention of the parties as expressed in the contract [31], and its breach will give rise to a right to claim damages, but the right to terminate the contract will depend on the nature of the breach, its foreseeability and consequences. However, as a general proposition, where an express term is found not to be a condition it may be presumed [32] to be intermediate in character unless the parties have clearly expressed an intention that the term is a warranty, particularly in cases where the term is capable of being breached in various ways [33].

Warranties have been regarded as not a vital term in a contract. A breach would only provide the aggrieved party to damages and does not permit the innocent party to repudiate the contract. For example, where a contractor finishes the project late it would amount to a breach of warranty and the employer is entitled to liquidated damages but not termination of the contract.

\section{CONCLUSION}

A review of existing literature and case law makes it clear that time stipulations in construction contracts may be conditions, intermediate (innominate) terms or warranties. It is important for contractors to recognise that where time stipulation is a condition, a failure to meet the specified time will be a fundamental breach of the agreement. At common law, time is deemed to be of the essence of a contract, however, a more liberal approach has been adopted in equity. By asking for performance when the promisee is guilty of delay is to ask the promisor to do something that he or she never agreed to.

The key message, therefore, is to ensure that the parties' project managers keep a watchful eye on events that might be subject to time limits and make certain (to the extent possible) that all claims are submitted within the time frames specified, as failure to do so would be expensive. It would perhaps be good practice for contractors to observe keeping good, orderly and clear records of communications, diary entries, minutes of meetings and the like, which will assist them in building a claim that may be time barred if it emerges later that waiver, estoppel or unconscionability could be proven.

\section{ENDNOTES}

1. Halsbury's Laws of Australia, at [110-8235]; Parkin v Thorold (1852) 16 Beav 59 at 66.

2. Ciavarella v Balmer (1983) 57 ALJR 632 at 634; Seton v Slade (1802) 7 Ves 265 at 273-274. 
3. Thomas, Trevor (2006) 'A failure to give notice and the defeasibility of time bars in construction contracts' 22 Building and Construction Law Journal, pp.342-343.

4. Lock v Bell [1931] 1 Ch 35 it was held in this case that time was of the essence in relation to the sale of a business as a going concern which included fluctuating stock.

5. DTR Nominees Pty Ltd v Mona Homes Pty Ltd (1978) 138 CLR 423 at 430.

6. Touche Ross \& Co $v$ Secretary of State (1983) 46 P\&CR 187 at 191; Cf Hydraulic Engineering Co Ltd v McHaffıe Goslett \& Co (1878) 4 QBD 670; The Post Chaser [1981] 2 Lloyd's Rep 695.

7. Gill \& Duffus SA v Societe pour l'Exportation des Sucres SA [1986] 1 Lloyd's Rep 322.

8. [1915] AC 386

9. Thesiger L.J. in Wright v. New Zealand Shipping Co. Ltd. (1878) 4 Ex. D. 165n. at p. 170

10. Aitken J.K., Elements of Drafting, at p. $123\left(8^{\text {th }}\right.$ ed 1991) Law Book Co, Sydney.

11. [1849] 154 ER 850.

12. (1970) CA 1BLR 111.

13. Bahr v Nicolay [No 2] (1988) 164 CLR 604 at 642.

14. (1962) 2 QB 26.

15. See Ankar Pty Ltd $v$ National Westmininster Finance (Australia) Ltd (1987) 162 CLR at 549; RDC Concrete Pte Ltd v Sato Kogyo (S) Pte Ltd [2007] 4 SLR 413; [2007] SGCA 39, See also JW Carter, Intermediate Terms Arrive in Australian and Singapore, Journal of Contract Law (2008) 24 JCL No 3.

16. See Suisse Atlantique Société d'Armement Maritime SA v NV Rotterdamsche Kolen Centrale [1967] 1 AC 361.

17. (1965) 114 CLR at 481.

18. McRae v Commonwealth Disposals Commission (1951) 84 CLR 377 at 398 (Dixon and Fullagar JJ);

19. [1989] 3 MLJ 216, [1989] SLR at 610.

20. IN Duncan Wallace QC, "The Stalling Architect/Engineer in Singapore" The Singapore Academy of Law Journal (2000), 12, pp.456-462.

21. The importance of this distinction was recognised by Isaacs $\mathrm{J}$ in Maynard v Goode (1926) 37 CLR 529 at 540.

22. [1993] 3 SLR 470; [1993] SGHC 161.

23. [1995] 2 SLR 609; [1995] SGHC 50.

24. [1993] 3 SLR 470; [1993] SGHC 161.

25. (1996) $12 \mathrm{BCL} 38$
26. Rashda Rana, "Hurdling the Time Bar", Construction Law International (2006), 1(2).

27. Lian Soon Construction Pte Ltd v Guan Qian Realty Pte Ltd (No.2) [2000] 1 SLR 295; [1999] SGHC 259

28. Ibid.

29. (1988) 164 CLR 387.

30. [2005] NSWSC 662 at [76].

31. Halsbury's Laws of Australia, at [110-2375].

32. See, for example, Cehave NV v Bremer Handelsgesellschaft $\mathrm{mbH}$ (The Hansa Nord) [1976] QB 44; [1975] 3 All ER 739; (presumption applied to quality term in sale of goods contract).

33. See, for example, Hongkong Fir Shipping Co Ltd v Kawasaki Kisen Kaisha Ltd [1962] 2 QB 26; [1962] 1 All ER 474. 